\title{
Does High Growth Create Value for Shareholders? Evidence from S\&P500 Firms
}

\author{
Levent Ataünal - Ali Osman Gürbüz - Asli Aybars*
}

\begin{abstract}
:
This paper investigates the relationship between growth rate and shareholder value creation, using a sample of 243 non-financial Standard and Poor's 500 (S\&P500) companies, which have 22 years of consecutive data available (1993-2014). Sustainable Growth Rate Model (SGR) is used to divide the sample into two groups as high growth firms and moderate growth firms. Using Panel data approach, it is shown that sales growth below sustainable growth rate (SGR) enhance shareholder value at a significantly higher rate compared to growth above sustainable growth rate. The findings suggest that shareholder value creation maximizes around sustainable growth rate and decreases sharply once SGR exceeded.
\end{abstract}

Key words: Shareholder value creation; Firm growth; Sustainable growth rate; Sales growth; Panel data analysis.

JEL classification: G30, G32.

\section{Introduction}

Corporate strategies are generally crafted to stimulate growth and profitability, two fundamental factors of firm value determination. General presumption is that sales revenue increase or firm growth proliferates shareholders' wealth. Yet, it is not verified with sufficient empirical evidence that, high growth generates value for shareholders. Some divergent views on the subject claim that growth at an excessive pace may lead to reduction in shareholders' wealth, especially when the firm forces its financial limits and accepts investments with returns less than the cost of capital, in other words, trades-off profits for growth.

Theoretically, investors try to forecast future growth of business and discount the expectation for future into the present value of the stock price. Stock prices fluctuate with realization and expectation differential. Companies create extra shareholder value only when they exceed those investors' expectations. When the company announces lower growth rate than investors had already discounted into the stock price, its stock price decreases as investors correct their over-estimated

Levent Ataünal; Istanbul Aydin University, Faculty of Economics and Administrative Sciences, Inonu Cad. No: 38, Kucukcekmece 34295, Istanbul, Turkey, <leventataunal@aydin.edu.tr〉.

Ali Osman Gürbüz; Istanbul Commerce University, Faculty of Business, Imrahor Cad., No: 90, Beyoglu 34445, Istanbul, Turkey, <ogurbuz@ticaret.edu.tr>.

Asli Aybars; Marmara University, Faculty of Business Administration, Ressam Namik Ismail Sok., No: 1, Bahcelievler 34180, Istanbul, Turkey, <asli.aybars@ marmara.edu.tr>. 
Ataünal, L. - Gürbüz, A. O. - Aybars, A.: Does High Growth Create Value for Shareholders? Evidence from S\&P500 Firms.

growth prospects. However, Fuller and Jensen (2002) stated that, to restore stock price, management often tries to achieve a growth rate significantly higher than the realistic growth rate of the industry in which they operate.

When confronted with pressure to grow, management is compelled to approve negative net present value projects or force their leverage levels to obtain additional capital required for the growth. But growth is beneficial only when the firm is growing healthily, that is, profits generated are also growing in-line with sales revenues. Unless profits provide the increased funding requirement stemming from the growth in sales revenues, the firm has to decrease its dividends or increase its debt level. Both are negatively perceived by the markets and usually result in share price drop, eventually destroying shareholder value.

The debate on limit of healthy growth still continues. The question "what is fast or high growth?" is not fully answered yet. Higgins (1977) proposed "Sustainable Growth Rate (SGR)" model as a practical limit for growing firms. The limit suggested by this model is that, new assets required for the additional sales should be funded by the profits retained in the company and the additional debt capacity of the growth. The model implicitly assumes that firms operate at their optimal financial leverage level or very close to it. No conclusive evidence is put forward in finance literature regarding how these limits work in practice. Further to this, there is no empirical verification on value creation dynamics of sales growth, which this study intends to elucidate.

This paper is organized as follows: section 2 gives an overview of the literature, section 3 describes the data selection and the methodology, section 4 presents empirical results and section 5 concludes.

\section{Literature Review}

For a firm to generate value for its shareholders, it must have investment opportunities with positive net present values. The return on equity on these investments must be above the cost of equity. Investment opportunities available to the firm may be considered as growth options. These options may include the investments to increase the profitability or volume of existing operations or expanding into profitable new businesses. The key role in value creation is played by expectations of investors who assess these options and form a future anticipation (Kasznik and McNichols, 2002). However, realizations forge expectations. When we look at firm performances for extended periods, realizations become the determinant of value creation. Expectations only determine the value until the next financial reporting, where the expectation is revised with announced figures.

Managers prefer to run large firms due to benefits they obtain while running bigger firms (Jensen and Meckling, 1976; Frydman and Saks, 2010). They 
prioritize growth over profits. However, growth rates are more volatile and unpredictable compared to profits (Geroski et al., 1997). Besides, profits and growth are weakly correlated (Lintner, 1964; Markman and Gartner, 2002). Maximizing growth does not necessarily result in maximization of shareholder value. Davidsson et al., (2009) suggested that a slowly growing firm with high profitability has a better chance of sustaining growth and becoming a high growth firm.

High growth expectation means higher stock price. However, Fuller and Jensen (2002) contend that overvalued stock price stemming from high growth anticipated can be as damaging to the firm as an undervalued stock. The firm is then forced to achieve those irrational growth levels anticipated by the market to preserve its stock price.

Ramezani et al., (2002) imply the existence of a growth rate where shareholder value may be maximized. They diagnose high growth firms by sorting companies according to their growth rates. But, each firm has its own growth potential. The threshold of over-growing should be different for each firm. Therefore for each firm, the maximization of shareholder value should be expected to occur at a different growth level in each observation period. We first have to postulate where this firm-specific maximization may occur, then look at empirical evidence. Sustainable Growth Rate model is already theorized an "affordable growth rate" for a firm.

Most of the prior studies conducted have attempted to investigate the determinants of shareholder value creation rather than specifically focusing on how growth impacts shareholder value. Further to this, the topic has mostly been explored within financial sector companies, particularly within banks. Fiordelisi and Molyneux (2010) examined the issue between the years 1998 and 2005 by utilizing a sample of European banks. Radic (2015) verified for Japanese banking industry that, credit risk and bank size are important factors affecting shareholder value. Oladele (2013) provided evidence that financial policy is an irrelevant factor. One study that has been performed on the non-financial sector have specifically evaluated the influence of financial leverage on shareholder value creation, which is measured by EVA and MVA (Market Value Added) (Atiyet, 2012). 
Ataünal, L. - Gürbüz, A. O. - Aybars, A.: Does High Growth Create Value for Shareholders? Evidence from S\&P500 Firms.

\section{The Data and Methodology}

Sustainable growth rate model (Higgins, 1977) is based on two assumptions. The first is that sales of a company can grow only as fast as its asset base. Secondly, as the equity grows, debt can grow at the same rate to allow maintaining a constant debt-equity ratio. As suggested by the 'Pecking Order Theory' (Myers, 1984; Myers, 2001), firm's first choice in financing is the earnings retained in the company. However, retaining profits at a higher proportion than its historical levels will have a negative impact on company's stock price. If we do not prefer to issue new equity, increase debt level and reduce dividend ratio (d), we will end up with one single achievable growth rate (Higgins, 1977).

$$
S G R=\frac{R O E x(1-d)}{1-R O E(1-d)},
$$

ROE (return on equity) in the above formula is calculated from the ending balance sheet, since beginning period and ending period leverage has to be the same.

Shareholder value creation is shaped by complex system of variables, but mainly depends on expected future cash generation, the cost of capital and the anticipated growth rate of the firm. Realizations adjust expectations and re-shape future expectations. When the firm's leverage is already at optimal level, the marginal cost of both equity and debt will be above their existing levels. Growth experienced with increased cost of capital is likely to destroy shareholder value.

The assumption that firms operate close to their optimal debt level can be challenged by empirical evidence on capital structure which contradicts, trade-off theory. The observation that high profits generally leads to low debt (Wald, 1999) is the main counter-evidence of trade-off theory. If trade-off theory is valid, we should observe that firms with higher profits must have higher debt to reduce their tax level. Shyam-Sunder and Myers (1999) contend that the pecking order is an excellent descriptor of corporate financing behaviour. However, they also confirm that, target adjustment model, when tested independently, also seems to perform well. In other words, both the Pecking Order Theory and the Static Trade-off Theory have some explanation power, although the Pecking Order Theory seems to better explain the reality.

In this study, it is aimed to test whether value creation rate by means of sales growth is same for moderately growing firms, and for high growth firms. Moderately growing firms are classified as the firms growing below their sustainable growth rates (SGR). High growth firms are composed of the firms which are growing beyond their sustainable growth rate. When we assume that most firms operate at or close to their optimal leverage levels, the debt level which minimizes cost of capital and which eventually maximize the shareholders' value, then growing above SGR should lead to value reduction. 
On the other hand, growth is not the only means to create shareholder value. Increased profit margin and diversification which reduces risk involved in the business may also create value for the shareholders. Measuring sole effect of diversification on value creation is not easy, as rate used by the market to discount future cash flow of the firm is not directly observable. However, effect of diversification on value creation is already included in the empirical study.

Prior studies defined fast growth without using a firm-specific benchmark. The threshold of fast growth must be defined discretely for each firm and for each period. Every firm has different growth potential at each observation period. With its sound assumptions, SGR emerges as a suitable option for firm-specific threshold of high growth.

For this study, longitudinal balanced data of 243 firms is collected for 22 years (between 1993 and 2014) via Bloomberg Database. The firms used in this study are selected from Standard Poor's 500 companies (S\&P500). The sample includes only non-financial firms which have 22 years of consecutive data available. All firms within S\&P500 fulfilling this criterion are selected into the sample. Regressions are run without the outliers (with extreme levels of data) of each observation period. As the collected data have the same cross-sectional units (firms) surveyed over time, panel data methodology is adopted for the analysis. Value creation is measured by total shareholder return (dependent variable), which is the rate of increase in the market capitalization of the firm adjusted for new capital issued and dividends paid. Firm growth is measured by the rate of increase in the net sales revenues of the firm over its net sales revenues in the previous year. For measuring growth, net sales growth is preferred. It is a more frequently used and referenced measure of growth in academic studies (Sheperd and Wilklund, 2009). 
Ataünal, L. - Gürbüz, A. O. - Aybars, A.: Does High Growth Create Value for Shareholders? Evidence from S\&P500 Firms.

Tab. 1: Variables used in the Study

\begin{tabular}{lr}
\hline Variable & Estimation of the Variable \\
\hline $\begin{array}{l}\text { Dependent: } \\
\text { TRS (Total }\end{array}$ & ${\text { (Market } \text { Cap }_{i t}-\text { Market Cap }_{i, t-1}-\text { New Capital Issued }_{i t}}_{\text {Return to }}$ \\
Shareholder) & + Dividend $\left._{i t}\right) /$ Market Cap $_{i, t-1}$ \\
\hline
\end{tabular}

\section{Independent:}

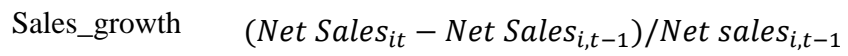

ch_profitability (Net Profits ${ }_{i t} /$ Net Sales $\left._{i t}\right)-\left(\right.$ Net Profits $_{i, t-1} /$ Net Sales $\left._{i, t-1}\right)$

cap_inc $\quad\left(\right.$ Paid $_{\text {Capital }}$ it - Paid Capital $\left._{i, t-1}\right) /$ Market Value of Equity $_{i, t-1}$

$\log ($ Assets $) \quad \log \left(\right.$ Total assets $\left.{ }_{i t}\right)$

ch_debt_ratio (Total Liabilities ${ }_{i t} /$ Total Assets $\left.{ }_{i t}\right)$

- (Total Liabilities ${ }_{i, t-1} /$ Total $_{\text {Assets }}$ Tit-1 $\left._{1}\right)$

ME_BE Market Value of Equity it $/$ Book Value of Equity $_{i t}$

Source: authorial computation.

Change in the level of profitability is used as a variable to measure effect of profitability on value creation. As the expectations are key drivers of stock prices, the change in the profitability is expected to better capture the effect on value creation. The logarithm of total assets is used as a proxy for company size. Firm size is considered to have a potential in influencing shareholder value creation and it is also controlled for in the studies of Ramezani et al. (2002), Fiordelisi and Molyneux (2010), and Radic (2015). It is envisaged that change in financial leverage (debt ratio) may have some impact on the value created for the shareholders. Increase in paid capital is expected to add value by preserving the optimal level of debt and equity during growth process. A proxy to measure the effect of capital increase on shareholder value creation is also added to capture this effect. Market to book value is generally used to distinguish firms with growth potential and the value firms. To capture the effect of this classification ME_BE ratio used as an explanatory variable in line with the study of Ramezani et al. (2002). In Table 1, dependent and independent variables employed in the study are given. 


\section{Empirical Findings}

Non-stationarity or unit root may result in spurious relations in regressions. Both dependent and independent variables are tested for unit roots with several different testing methodologies. The results revealed no unit root problem within the chosen variables.

The study is concerned to detect the effect of change in sales volume on the total value created for the shareholders in each observation period. The study does not aim to find all variables that are likely to explain shareholders' return. Nevertheless, some control variables as given in Table 1 which may have impact on shareholder value created are employed. Since multicollinearity may distort calculated coefficients of independent variables, correlations between the independent variables are examined. Highest correlation observed 0.34, is between ch_profitability and sales_growth. Although it will have some impact on the estimated coefficients, it is not expected to change them dramatically. To isolate the unique effect of sales_growth on shareholder value, the regressions are also repeated without other independent variables to confirm the robustness of calculated coefficient for sales_growth. Some outliers in the dataset (observations with extreme values) in total shareholder turn and sales growth are removed from the sample. These extreme observations accounted only $0.1 \%$ of total observations. As we are only interested in sales growth, observations of sales revenue decreases are ignored in the regressions.

Before choosing the panel method to analyse the dataset, several methods are employed (Table 2). Breusch - Pagan Test (Breusch and Pagan, 1980) provided evidence for the model's error terms not being independently and identically distributed (Table 2). Consequently, GLS (generalized least squares) estimation appeared to be better fitting to our sample. Hausman Test (Hausman and Taylor, 1981) implied a correlation between random effects and regressors (Table 2). Thus, Fixed Effects Model seemed to better fit to our dataset. Redundant Fixed Effects Likelihood Test suggested time effects to be significantly stronger compared to cross-sectional effects. F-test and Chi-square tests did not reject the null hypothesis that the cross-section effects are redundant. As expected all stock prices are influenced from the periodic market conditions. These market influences in the stock prices, which induce shareholder return are disclosed as time effects in the model.

The tests pointed fixed time effects model as the suitable panel model to analyse the data. Therefore, in the analysis, GLS (Generalized Least Squares) with fixed time effects model is used as the estimation method. However, in all the methods employed although the coefficients somewhat differed, sales growth coefficient remained positive and highly significant. Further to this, magnitude of sales_growth coefficient did not change to a large extent (Table 2). 
Ataünal, L. - Gürbüz, A. O. - Aybars, A.: Does High Growth Create Value for Shareholders? Evidence from S\&P500 Firms.

The regression equation we estimated is as follows:

$$
\begin{aligned}
T R S_{i t}= & \beta_{0}+\beta_{1} \text { sales_growth }_{i t}+\beta_{2} \text { ch_profitability }_{i t}+\beta_{3} \text { cap_inc }_{i t}+ \\
& \beta_{4} \log (\text { assets })_{i t}+\beta_{5} \text { ch_debt_ratio }_{i t}+\beta_{6} \text { me_b }_{-} e_{i t}+\varepsilon_{i t},
\end{aligned}
$$

Sustainable Growth Rate of each firm in the sample is calculated for every observation period (year) with equation (1). Then, the observations are divided into two groups, growth below sustainable growth rate (SGR) and growth above sustainable growth rate (Table 3 ). In the group in which growth rate is limited with the SGR of firm in the period, all explanatory variables except $\log$ (assets) are highly significant $(\mathrm{p}<0.01)$, validating the strong influence of explanatory variables on shareholder return. Size of the firm does not seem to be a factor that affects shareholder value. Likewise, the majority of prior studies deny such relation.

Sales_growth seems to have significant influence on shareholder value created. A dollar increase in sales revenues seems to bring 0.7 dollars of value to shareholders on average when the growth rate of the firm does not exceed its SGR. Interestingly, capital increase also creates value for the shareholders. Firms increase their capital to fund their sizeable investments or to improve their debtratio. Both may contribute positively to shareholder value. Within fast growth (growth rate>SGR), it is observed that the sales_growth coefficient dropped to 0.39 from 0.71 and ch_profitability coefficient became insignificant. When we repeated the regression estimation without control variables, similarly sales_growth coefficient went down to 0.40 from 0.85 , preserving its high significance. 
Tab. 2: Different Methods Employed

\begin{tabular}{|c|c|c|c|c|c|}
\hline & $\begin{array}{l}\text { Fixed Effects } \\
\text { (cross-section) }\end{array}$ & $\begin{array}{l}\text { Fixed Effects } \\
\text { (Time) }\end{array}$ & $\begin{array}{l}\text { Two-way } \\
\text { Fixed Effects }\end{array}$ & $\begin{array}{l}\text { GLS (Time } \\
\text { random effects) }\end{array}$ & $\begin{array}{l}\text { GLS Fixed Effects } \\
\text { (Time weights) }\end{array}$ \\
\hline \multicolumn{6}{|l|}{ Dependent Variable } \\
\hline \multicolumn{6}{|l|}{ TRS } \\
\hline \multicolumn{6}{|l|}{ Independent Variables } \\
\hline $\mathrm{C}$ & $0.549311^{* * *}$ & $0.299131^{* * *}$ & $0.780327^{* * *}$ & $0.303111^{* * *}$ & $0.226924^{* * *}$ \\
\hline SALES_GROWTH & $0.448445^{* * *}$ & $0.484489^{* * *}$ & $0.460516^{* * *}$ & $0.484149^{* * *}$ & $0.431124^{* * 8}$ \\
\hline CH_PROFITABILITY & $0.073758^{* * *}$ & $0.047832^{88}$ & $0.044375^{*}$ & $0.049860^{* 8}$ & 0.002526 \\
\hline CAP_INC & $1.370542^{* * *}$ & $1.099614^{* * *}$ & $1.244584^{* * *}$ & $1.105457^{* * *}$ & $0.826000^{* * *}$ \\
\hline LOG(ASSETS) & $-0.049831^{* * *}$ & $-0.022058^{* * *}$ & $-0.075513^{* * *}$ & $-0.022191^{* * *}$ & $-0.012290^{* * *}$ \\
\hline CH_DEBT_RATTO & $-0.861672^{* * *}$ & $-0.761433^{* * *}$ & $-0.726895^{* * *}$ & $-0.774233^{* * *}$ & $-0.718203^{* * *}$ \\
\hline ME_BE & $0.000783^{88}$ & $0.000644^{88}$ & $0.000577^{8}$ & $0.000658^{88}$ & $0.000328^{8}$ \\
\hline Adjusted R-squared & 0.110076 & 0.229852 & 0.221609 & 0.116427 & 0.306093 \\
\hline F Statistics & $3.004^{* * *}$ & $47.12^{* * *}$ & $5.27^{* * *}$ & $89.24^{* * *}$ & $69.17^{* * *}$ \\
\hline $\begin{array}{l}\text { Hausman Test, } \mathrm{X}^{2} \\
\text { (prefers FixedEffects) }\end{array}$ & & & & $28.903785^{* * *}$ & \\
\hline \multicolumn{6}{|l|}{$\begin{array}{l}\text { Breusch-Pagan (LM } \\
\text { test) }\end{array}$} \\
\hline Cros5-section & & & & $10.46745^{* * *}$ & \\
\hline Period & & & & $5235.131^{* * *}$ & \\
\hline Both sides & & & & $5245.598^{* * *}$ & \\
\hline $\begin{array}{l}\text { Redundant FE Effects } \\
\text { Likelihood }\end{array}$ & & & & Prefers Period $\mathrm{H}$ & ffects \\
\hline
\end{tabular}

Source: authorial computation.

Note: *** $\mathrm{P}<0.01, * * \mathrm{P}<0.05, * \mathrm{P}<0.10$.

In other words, removing all other independent variables does not change the magnitude of growth coefficient much, confirming the robustness of results. Interestingly, when we run regression estimations without the control variables, adjusted $\mathrm{R}^{2}$ only slightly decreases (Table 3 ). It verifies that sales_growth is the single most influential variable among the explanatory variables chosen.

Clearly, growing at a rate below the sustainable growth rate (SGR) creates considerably more value for shareholders, compared to growing at a rate above SGR. The growth coefficient is highly significant in both samples confirming the strength of the variable in the determination of the shareholder value. In addition to persistence of significance, the sign remains the same. 
Ataünal, L. - Gürbüz, A. O. - Aybars, A.: Does High Growth Create Value for Shareholders? Evidence from S\&P500 Firms.

Regardless of the estimation technique, the sales_growth is shown to contribute positively to the shareholder value. All the regression results point to a very robust positive relationship between shareholder value and sales_growth. However, the impact of change in profitability rate on shareholder value is statistically significant only when the growth rate does not exceed SGR. The effect of profitability change depends on whether that change occurs without forcing the financial limits or not.

\section{Tab. 3: FE GLS for two samples}

\begin{tabular}{lrrrr}
\hline $\begin{array}{l}\text { GLS Fixed Effects } \\
\text { (time weights) }\end{array}$ & Sales Growth $\angle=$ SGR & Sales Growth $\approx$ SGR & Sales Growth $\angle=$ SGR & Sales Growth $\approx$ SGR \\
\hline Dependent Variable: TRS & $0.088748^{* *}$ & $0.296664^{* * *}$ & $0.091324^{* * *}$ & $0.138354^{* * *}$ \\
C & $0.711044^{* * *}$ & $0.391715^{* * *}$ & $0.854520^{* * *}$ & $0.400625^{* * *}$ \\
SALES_GROWTH & $0.467854^{* * *}$ & -0.016769 & & \\
CH_PROFITABILITY & $2.109841^{* * *}$ & $0.393007^{* *}$ & & \\
CAP_INC & -0.006027 & $-0.018161^{* * *}$ & & \\
LOG(ASSETS) & $-0.601224^{* * *}$ & $-0.615733^{* * *}$ & & \\
CH_DEBT_RATIO & $0.009832^{* * *}$ & 0.000198 & & \\
ME_BE & 0.350225 & 0.293587 & 0.290396 & 0.289399 \\
Adjusted R-squared & $45.73649^{* * *}$ & $30.71552^{* * *}$ & $43.05394^{* * *}$ & $37.05211^{* * *}$ \\
F-statistic & &
\end{tabular}

Source: authorial computation.

Note: *** $\mathrm{P}<0.01, * * \mathrm{P}<0.05, * \mathrm{P}<0.10$.

Increase in debt-ratio always contributes negatively to the shareholder value. Whatever the growth level is, the magnitude of impact of ch_debt_ratio on shareholder value, remains the same. $M E \_B E$ becomes insignificant at growth levels above SGR, however the magnitude of coefficient is very small both below and above SGR. The coefficient of $\log$ (assets) which is used as a proxy to capture the effect of size on shareholder value, is also very small, indicating no effect of size on value created. Nevertheless, it becomes significant at the growth rates above SGR.

To observe the behavior of sales_growth coefficient at more extreme growth levels, we estimated the sales_growth coefficient with growth intervals of 5\% above SGR and below SGR. The regression results are summarized in Table 4. The regression results exhibit a clear breaking point on value creation rate around SGR level (Figure 1). The results also exhibit some decreasing trend in the coefficient of sales_growth, beyond SGR.

When sales_growth is used as a single explanatory variable, its coefficient goes down to 0.40 from 0.85 as soon as the firm's growth rate exceeds SGR (Table 3). 
This implies that shareholder value creation by means of sales growth maximizes when the growth rate reaches SGR. When the growth rate of sales exceeds SGR, the rate of value creation rate decreases. In order recuperate the value lost, the firm has to achieve considerably higher growth. In other words, if the firm cannot grow twice as big as its SGR, it is better for the firm to restrain its growth level at its sustainable growth rate (SGR) estimated for the period. It is further suggested that, value creation rate may continue to decrease as the difference between the growth rate and SGR (or excess_growth) expands (Table 4). Therefore, the firm has to grow more than twice to recover the value lost resulted from surpassing its SGR. The trend in the change of the sales_growth coefficient is given in Figure 1. Apparently there is a cut-off in the value creation rate at the point of sustainable growth rate.

\section{Tab. 4: Estimated Growth Coefficients at Different Growth Levels}

\begin{tabular}{lrr}
\hline Sample Restriction & SALES_GROWTH & F-statistic \\
\hline EXCESS_GROWTH<-0.20 & $0.779177 * * *$ & $7.91 * * *$ \\
EXCESS_GROWTH<-0.15 & $0.874377 * * *$ & $15.37 * * *$ \\
EXCESS_GROWTH<-0.10 & $0.723927 * * *$ & $19.64 * * *$ \\
EXCESS_GROWTH<-0.05 & $0.745422 * * *$ & $30.41 * * *$ \\
EXCESS_GROWTH<0 & $0.711044 * * *$ & $45.74 * * *$ \\
EXCESS_GROWTH $>0$ & $0.391715 * * *$ & $30.72 * * *$ \\
EXCESS_GROWTH $>0.05$ & $0.376259 * * *$ & $21.04 * * *$ \\
EXCESS_GROWTH $>0.10$ & $0.365026 * * *$ & $14.04 * * *$ \\
EXCESS_GROWTH $>0.15$ & $0.34188^{* * * *}$ & $11.42 * * *$ \\
EXCESS_GROWTH $>0.20$ & $0.331261 * * *$ & $8.02 * * *$ \\
EXCESS_GROWTH $>0.25$ & $0.344462 * * *$ & $6.38 * * *$ \\
EXCESS_GROWTH $>0.30$ & $0.326277 * * *$ & $5.30 * * *$ \\
\hline SOUICE: & &
\end{tabular}

Source: authorial computation.

Note: *** $\mathrm{P}<0.01, * * \mathrm{P}<0.05$, * $\mathrm{P}<0.10$. 
Ataünal, L. - Gürbüz, A. O. - Aybars, A.: Does High Growth Create Value for Shareholders? Evidence from S\&P500 Firms.

\section{Fig. 1: Shareholder Value Creation at Different Growth levels}

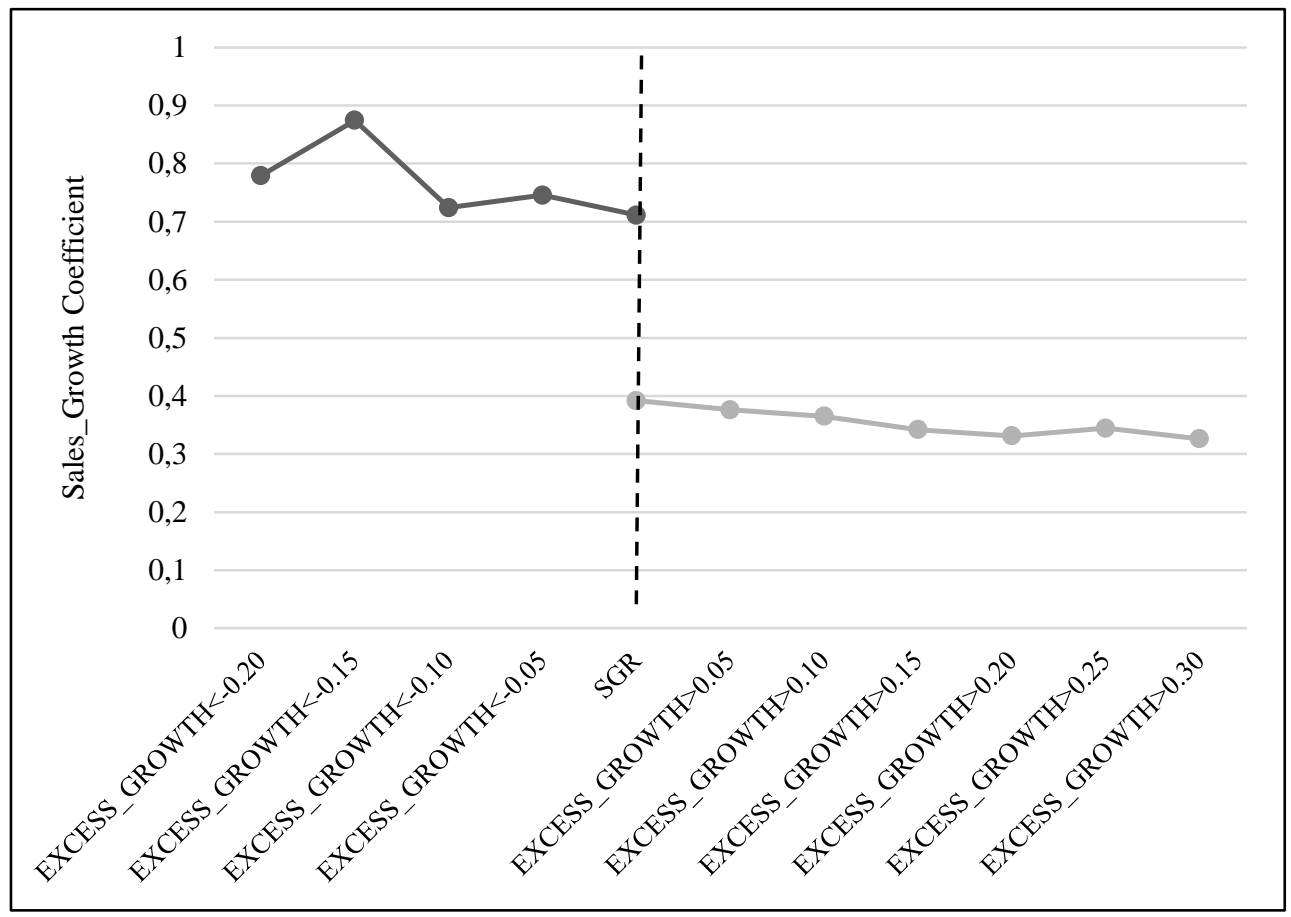

Source: authorial computation.

\section{Conclusion}

Sustainable growth rate is the rate which firm finances its growth without issuing new capital and without increasing its leverage. Growth above sustainable growth rate can only be achieved either by issuing new capital or by increasing debt level of the company. It is expected that, when the cost of debt is constant, increasing financial leverage should decrease cost of capital of the firm due to tax advantage of debt. However, unless the company is already operating below its optimal debt level increasing the financial leverage may increase cost of capital. Net present value of the firm, which is calculated with increased cost of capital, will fall.

Access to capital may facilitate growth but it usually does it at the expense of profitability (Davidsson, Steffens, Fitzsimmons, 2009). Firms, when they find necessary funds, choose to grow fast at the expense of deteriorating profits. Higher investments increase the revenues but also create large appetite for cash and result in lower free cash flows which are the major inputs in value determination. Underlying forces of rapid growth may lead into lower value for the shareholders. 
This study is focused on the contribution of sales growth in determination of shareholder value. It is empirically demonstrated that moderate growth in sales, that is, growth under sustainable growth rate (SGR), creates significantly more value for the shareholders compared to sales growth exceeding SGR. It is observed that firms are actually destroying value when their growth rates exceed SGR. Only after their growth rate substantially surpasses SGR, they start recuperating the lost value of their shareholders.

\section{References}

Atiyet, B. A., 2012. The Impact of Financing Decision on the Shareholder Value Creation. Journal of Business Studies Quarterly 1, 44-63.

Breusch, T. S., Pagan, A. R., 1980. The Lagrange Multiplier Test and Its Applications to Model Specification in Econometrics. Review of Economic Studies 1, 239-253. DOI: 10.2307/2297111.

Davidsson, P., Steffens, P., Fitzsimmons, J., 2009. Growing Profitable or Growing from Profits: Putting the Horse in front of the Cart. Journal of Business Venturing 4, 388-406. DOI: 10.1016/j.jbusvent.2008.04.003.

Fiordelisi, F., Molyneux, P., 2010. The Determinants of Shareholder Value in European Banking. Journal of Banking \& Finance 6, 1189-1200. DOI: 10.1016/j.jbankfin.2009.11.018.

Frydman, C., Saks, R. E., 2010. Executive Compensation: A New View from Long-Term Perspective, 1936-2005. The Review of Financial Studies 5, 20992138. DOI: $10.1093 / \mathrm{rfs} / \mathrm{hhp} 120$.

Fuller, J., Jensen, M. C., 2002. Just Say No to Wall Street: Courageous CEOs are putting a stop to the earnings game and we will all be better off for it. Journal of Applied Corporate Finance 4, 41-46. DOI: 10.1111/j.1745-6622.2002. tb00447.x.

Geroski, P. A., Machin, S. J., Walters, C. F., 1997. Corporate Growth and Profitability, The Journal of Industrial Economics 2, 171-189. DOI: 10.1111/14676451.00042.

Hausman, J. A., Taylor, W. E., 1981. Panel Data and Unobservable Individual Effects. Econometrics 6, 1377-1398. DOI: 10.1016/0304-4076(81)90085-3.

Higgins, R. C., 1977. How Much Growth Can a Firm Afford. Financial Management 3, 7-16. DOI: 10.2307/3665251.

Jensen, M. C., Meckling, W. H., 1976. Theory of the Firm: Managerial behavior, Agency Costs, and Ownership Structure. Journal of Financial Economics 4, 305360. DOI: $10.1016 / 0304-405 \times(76) 90026-x$. 
Ataünal, L. - Gürbüz, A. O. - Aybars, A.: Does High Growth Create Value for Shareholders? Evidence from S\&P500 Firms.

Kasznik, R., McNichols, M. F., 2002. Does Meeting Earnings Expectations Matter? Evidence from Analyst Forecast Revisions and Share Prices. Journal of Accounting Research 3, 727-759. DOI: 10.1111/1475-679x.00069.

Lintner, J., 1964. Optimal Dividends and Corporate Growth under Uncertainty. The Quarterly Journal of Economics 1, 49-95. DOI: 10.2307/1880545.

Markman, G. D., Gartner, W. B., 2002. Is Extraordinary Growth Profitable? A Study of Inc. 500 High Growth Companies. Entrepreneurship Theory and Practice 1, 65-75. DOI: 10.1111/1540-8520.271004.

Myers, S. C., 1984. The Capital Structure Puzzle. The Journal of Finance 3, 575592. DOI: $10.2307 / 2327916$.

Myers, S. C., 2001. Capital Structure. The Journal of Economic Perspectives 2, 81-102. DOI: 10.1257/jep.15.2.81.

Oladele, K. O., 2013. The Determinants of Value Creation in the Nigerian Banking Industry: Panel Evidence. International Journal of Business and Social Science 3, 90-101.

Radic, N., 2015. Shareholder Value Creation in Japanese Banking. Journal of Banking \& Finance 3, 199-207. DOI: 10.1016/j.jbankfin.2014.09.014.

Ramezani, C., Soenen, L., Jung, A., 2002. Growth, Corporate Profitability and ShareholderValue Creation. Financial Analyst Journal 6, 56-67. DOI: 10.2469/faj.v58.n6.2486.

Sheperd, D., Wiklund, J., 2009. Are We Comparing Apples with Apples or Apples with Oranges? Appropriateness of Knowledge Accumulation Across Growth Studies. Entrepreneurship: Theory and Practice 1, 105-123. DOI: 10.1111/j.15406520.2008.00282.x.

Shyam, S. L., Myers, S. C., 1999. Testing Static Trade-off against Pecking Order Models of Capital Structure. Journal of Financial Economics 51, 219-244. DOI: 10.1016/S0304-405X(98)00051-8.

Wald, J. K., 1999. How Firm Characteristics Affect Capital Structure: An International Comparison. Journal of Financial Research 2, 161-187. DOI: 10.1111/j.1475-6803.1999.tb00721.x. 